\title{
What determines the varying relation of case and agreement? Evidence from the Ugric languages
}

\author{
KATALIN É. KISS*
}

Research Institute for Linguistics, Budapest, Hungary

Received: March 17, 2020 • Accepted: October 29, 2020

(C) 2020 The Author(s)

\begin{abstract}
Agreement and case assignment can be interdependent, partially independent, or independent of each other (Baker \& Vinokurova 2010; Baker 2014, 2015). These parametric options appear to have random distribution across languages. This paper claims on the basis of the comparison of the Ugric languages (Mansi, Khanty, and Hungarian) that the correlation of case and agreement or the lack of it may not be random. A strict correlation of case and agreement is attested in sentence structures displaying a fusion of grammatical functions and discourse roles. When these roles are encoded in distinct clausal domains, case and agreement have separate functions and licensing conditions, with case marking grammatical functions, and agreement associated with discourse roles. At the same time, relics of their former syntactic interdependence may survive in morphology, resulting in a partial correlation between case and agreement. It is shown that dependent case theory can account for the whole range of variation attested in the relation of case and agreement.
\end{abstract}

\section{KEYWORDS}

case, agreement, dependent case theory, Ob-Ugric, differential object marking

\section{INTRODUCTION}

As shown by Baker and Vinokurova (2010) and Baker (2014, 2015), agreement and case assignment can be (i) interdependent, (ii) partially independent, or (iii) independent of each other. These parametric options appear to have random distribution across languages. This paper argues that the correlation of case and agreement or the lack of is not random in the Ugric languages (Mansi, Khanty, and Hungarian). A strict correlation of case and agreement is attested

\footnotetext{
*Corresponding author. E-mail: e.kiss.katalin@nytud.hu
} 
in a language that displays a fusion of grammatical functions and discourse roles. When these roles are encoded in distinct clausal domains, case and agreement have separate licensing conditions, and they are free from each other. Case encodes grammatical function (relative prominence in the thematic hierarchy of arguments), whereas agreement tracks discourse role (topicality). At the same time, relics of their former syntactic interdependence may survive in morphology, resulting in a partial correlation between case and agreement. It is argued that dependent case theory can account for the whole range of variation attested in the relation of case and agreement.

The paper is structured as follows: Section 2 summarizes current views about the relation of agreement and case. Sections 3-5 examine the relation of agreement and case in the Ugric branch of the Uralic language family. Section 3 analyzes the situation in Eastern Mansi, an extinct dialect displaying fused discourse roles and grammatical functions. Section 4 describes the relation of case and agreement in extant Ob-Ugric dialects, where the intertwining of the secondary topic role and the object function started to unravel. Section 5 discusses agreement and case in Hungarian, a language with discourse roles separated from grammatical functions. Section 6 is a conclusion.

\section{BACKGROUND}

In Chomskyan case theory (Chomsky 2000, 2001), an overt NP must have abstract Case, which may or may not be realized in the form of a case morpheme. Abstract Case is either inherent (i.e., thematically determined), or structural. Structural Case is assigned to the closest NP in an A-position by a functional head F if an Agree relation holds between F and the NP. Abstract Agree may - but need not - be realized as morphological agreement. For Agree to happen, F must c-command the NP, and they must share the same feature specification, valued on the NP and unvalued on F. The NP must be active by having an unvalued Case feature. In nominative-accusative languages, the source of the nominative Case feature is T, and the source of the accusative Case feature is v. An overt NP with no Case is ruled out by the Case Filter, i.e., Case assignment amounts to NP licensing. Morphological case is the postsyntactic morphological realization of abstract Case - in languages which have the appropriate morphological resources. For a recent defense of this theory, see Legate (2008).

The apparent dissociation between morphological case and abstract Case in languages like Icelandic, and between case licensing and agreement in languages like Amharic (Baker 2012) have motivated a version of case theory without abstract Case, the theory of dependent case (Marantz 1991; Bobaljik 2008). In this framework, case assignment takes place in Morphological Structure, according to the following disjunctive hierarchy: i. lexically governed/inherent case; ii. dependent case; iii. unmarked case; iv. default case (Marantz 1991: 24). I.e., lexical and inherent cases are assigned first. Dependent case is assigned when lexical/inherent case realization leaves two NPs caseless in the same local domain. In nominative-accusative languages, the structurally less prominent NP obtains accusative case, as determined in (1):

(1) If there are two distinct NPs in the same spellout domain such that NP1 c-commands NP2, then value the case feature of NP2 as accusative unless NP1 has already been marked for case. (Baker 2015: 48)

NP1 - as well as an only NP without inherent case in a spellout domain - get unmarked nominative. In Baker's version of dependent case theory, case assignment takes place in syntax, and the Case Filter is in force. 
Although the theory of dependent case was put forth as an alternative to Chomskyan case theory, Baker and Vinokurova's (2010) version also acknowledges the possibility of case assignment by a functional head via agreement - albeit morphological agreement rather than abstract Agree. They argue that the two theories are not alternative models of the same linguistic phenomena but represent two modes of case assignment. The two ways of case assignment are complementary across languages and can be complementary also within one and the same language. In Sakha, for example, nominative and genitive are assigned by functional heads via agreement, whereas accusative case and dative case are assigned by configurational rules.

As shown by Baker (2015), the alternative possibilities of case assignment via agreement and via case assignment by configurational rules result in varying relations between agreement and structural case in the languages of the world. Case and agreement can be (i) interdependent, (ii) independent, or (iii) partially independent of each other. The interdependence of case and agreement is claimed to usually arise as a result of case licensed by agreement, as in the case of nominative and genitive in Sakha, nominative in some Indo-European languages, and nominative-absolutive in Kurmanji, but agreement licensed by case (case-sensitive agreement in the terminology of Bobaljik (2008) and Baker (2015)) is also reported e.g. in the case of agreement with ergative subjects in Ingush and other Caucasian languages. Case is independent of agreement e.g. in languages like Burushaski and Warlpiri, where subject agreement is possible with both ergative subjects and absolutive subjects, and object agreement is possible with both dative objects and accusative/absolutive objects (Baker 2008). ${ }^{1}$ The correlation may only hold in the case of nominative, but not in the case of accusative. In languages that case-mark all objects, object-verb agreement can be completely absent, or can only extend to a subset of accusative objects - as is the case in Hungarian.

This paper will illustrate the observed possibilities in the relation of case and agreement with languages of the Ugric branch of Uralic, and will argue that the correlation of case and agreement is a consequence of the fusion of grammatical functions and discourse roles.

The Ugric branch of the Uralic language family includes Hungarian, Khanty and Mansi. Khanty and Mansi, the so-called Ob-Ugric languages, are severely endangered languages spoken in Western Siberia (Abondolo 1998). In the past hundred years, they have been subject to increasing Russian dominance, but until recently, they have preserved the basic grammatical properties reconstructed for Proto-Ugric. Hungarian has removed from them both geographically and grammatically; it has been influenced by Indo-European languages. Conservative Ob-Ugric dialects showing little impact of 20th century Russification, present-day Ob-Ugric dialects under strong Russian influence, and Hungarian represent subsequent stages of a developmental path from a strictly SOV sentence structure with fused grammatical and discourse roles to a head-initial sentence structure with a separate layer for discourse functions (cf. Asztalos et al. 2017; Csepregi 2019; Dékány, Gugán, \& Tánczos 2020; É. Kiss 2014). It will be argued below that these stages instantiate the three parametric options of case-agreement relations identified above.

\section{CORRELATION OF CASE AND AGREEMENT: EASTERN MANSI}

\subsection{Fusion of the subject and topic roles}

Eastern Mansi (EM) texts recorded between 1868 and 1905 show this now extinct dialect to be strictly SOV, displaying a fusion of the subject and topic roles. The Eastern Mansi subject also

${ }^{1}$ Legate (2008) accounts for Case-assignment in Warlpiri in the Chomskyan framework. 
functions as the topic of the sentence, denoting a discourse-given referent, that which the sentence is about. Accordingly, it must be represented by a [+referential], and [+specific] constituent. If the underlying subject is not appropriately topical, i.e., it is [-referential] and/or [-specific], passivization is used to demote it to a by-phrase, and to raise the highest [+referential, +specific] argument into subject-topic position (Kulonen 1989; Kiparsky 2013). In (2), a [+referential, +specific] 2nd person pronoun assumes the subject-topic role. As is common in Ugric, the overt pronoun, cross-referenced on the verb, is dropped. The verb has a $-w$ - passive morpheme, and the underlying subject, if spelled out, is supplied with the -nə, - $n$, -ən lative case ending. (According to Honti (1982), -nə, -n, -ən has also assumed the instrument role.)

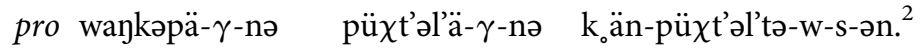

$$
\begin{aligned}
& \text { handspike-DU-LAT hammer-DU-LAT out-forge-PASS-PST-2SG }
\end{aligned}
$$

'You were forged by a handspike and a hammer.'

(EM, Kulonen 1989: 86)

Passivization is invariably triggered if the underlying subject of the sentence is an indefinite or interrogative pronoun, and the internal argument is referential and specific, as illustrated in (3)-(4):

a. Äjnə-tēnät töäś, al-kən-nə wöär-wə-s. food-3sG ready one-who-LAT make-PASS-PST.3SG 'His food is ready, it has been made by someone.'

(EM, Kulonen 1989: 280)

b. Kэm öät'i-när-nə öät kan-wə.

man no-thing-LAT not stick-PASS.3SG

'Nothing sticks on the man.' Lit. 'The man is stuck (on) by nothing.'

(EM, Kulonen 1989: 185)

(4)

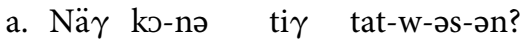

you who-LAT here bring-PASS-PST-2SG

'Who brought you here?' Lit. 'By whom have you been brought here?'

(EM, Kulonen 1989: 280)

b. Oär nisənär-nə partə $\gamma$-röät-w-əs?

weir what-LAT in.two-break-PASS-PST.3SG

'What broke the weir in two?' Lit.: 'What was the weir broken by?'

(EM, Kulonen 1989: 128)

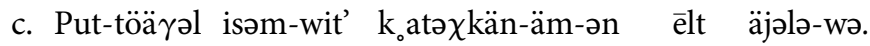

pot-ful hot-water which.of.us.two-LAT first drink-PASS.3sG

'Which of us will first drink the potful of hot water?'Lit.: 'Which of us is the potful of hot water first drunk by?'

(EM, Kulonen 1989: 281)

\footnotetext{
${ }^{2}$ The authors I cite use different spelling conventions, which I preserve. They may also differ in the alignment of epenthetic vowels.
} 
A subject question only occurs in unaccusative sentences where the subject is the only argument of the verb. Such examples are extremely rare; they are versions of (5), which does not contain enough material to establish whether its subject is externalized, and whether the verb agrees with it (as the 3SG agreement suffix is phonologically null):

$$
\begin{aligned}
& \text { Tət nəsənæ:r jəmt-əs? } \\
& \text { here what happen-PST.3sG } \\
& \text { 'What happened here?' }
\end{aligned}
$$

Passivization also takes place in unaccusative and unergative sentences with a non-specific subject if a goal, or location, or temporal constituent satisfies the referentiality and specificity criteria of topichood:
a. (Mā-n
ural'tēel-ən!)
pro wōr-jiw-ən
tēl-w-วs?
land-2sG see-IMP.2sG
forest-tree-LAT grow-PASS-PST.3SG
'(Look at your land!) Have forest trees grown on it?'
Lit.: 'Has it been grown by forest trees?'
(EM, Kulonen 1989: 188)
b. Tōrəm lāwə-m ńila ēt jon $\gamma$ a-w-et.
God order-PRTP.PST four night play-PAss.3PL
'People play during the four nights ordered by God.'
Lit.: 'The four nights ordered by God are being played [through].'

(EM, Kulonen 1989: 252)

Presentative sentences with a non-specific underlying subject are also often passivized, with the only complement demoted to adjunct. The subject position apparently remains empty, unless we hypothesize there an invisible spatiotemporal pro:

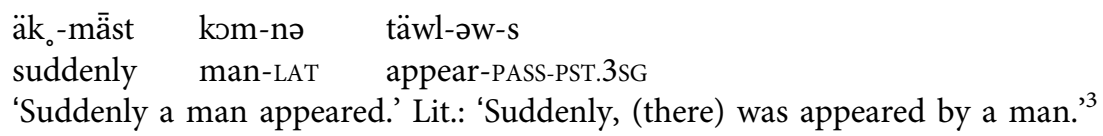

(EM, Kulonen 1989: 184)

As is clear from the above examples, NP-movement in Ob-Ugric is motivated not by a need for case but by discourse-structural requirements. A topical constituent can be NPmoved also when it has inherent (e.g., lative or locative) case. The inherent case suffix or case-like postposition of the NP-moved constituent is overwritten in subject position by nominative case. A [+human] goal, for example, is marked by the postposition pālt 'to'

\footnotetext{
${ }^{3}$ Descriptions of Ob-Ugric syntax, including such theoretically diverse analyses as Lavotha (1958), Gulya (1970), Honti (1982), Kálmán (1976a, b), Kulonen (1989), Nikolaeva (1999), Skribnik (2001), Kiparsky (2013), and others, have never questioned the passive status of the construction illustrated in (6)-(7). It satisfies the following standard criteria of passive: i. it contrasts with another construction, the active; ii. the subject of the active corresponds to a non-obligatory oblique phrase of the passive or is not overtly expressed; iii. the subject of the passive, if there is one, corresponds to an argument of the active; iv. the construction displays special morphological marking of the verb; v. the construction is productive (as opposed to the various lexically constrained decausativizing suffixes of these languages).
} 
(8a). When the goal argument is targeted by NP movement, it surfaces in unmarked nominative case $(8 b-c)$ :
a. pro

$$
\text { two-DU.3sG to come-PST.3sG }
$$

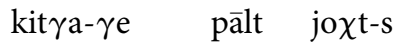

'She came to her two ones [two companions].'

(EM, Kulonen 1989: 159)

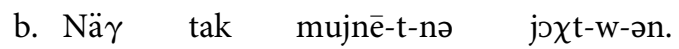
you so guest-PL-LAT come-PASS-2SG

'Guests come to you.'Lit.: 'You will be come by guests.' (EM, Kulonen 1989: 158)
c. pro rä $\chi_{\circ}$-säm-nə pä̈t-wə, wit'-säm-nə pät-wə. rain-drop-LAT fall-PASS.3SG water-drop-LAT fall-PASS.3sG

'A raindrop falls on him, a water-drop falls on him.'

Lit.: 'He is fallen by a raindrop, he is fallen by a water-drop.' (EM, Kulonen 1989: 164)

In (9), a locative argument is moved into subject position, losing its locative $-t$ suffix:

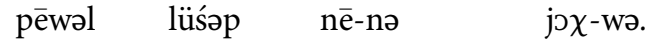

$$
\begin{aligned}
& \text { village crying woman-LAT go.around-PASs.3sG }
\end{aligned}
$$

'A crying woman is going around in the village.'

Lit.: 'The village is being gone around by a crying woman.' (EM, Kulonen 1989: 160)

Multiple case-assignment to a constituent is not unique to the Ob-Ugric languages. It has been argued for in the case of English pseudo-passives by Richards (2017), and it has also been pointed out in different syntactic environments in Cuzco Quechua and Korean (Baker 2015: 281-284), and in Amis (Chen 2018). It can result in case stacking, or the higher case can overwrite the lower one, as happens in Ob-Ugric. An alternative account of the Ob-Ugric facts in (6)-(9), suggested by an anonymous reviewer, would be to assume that the inherent cases are $\mathrm{P}$ heads, which are stranded in passive constructions, and $\mathrm{P}$ is not pronounced when its complement is null.

The non-standard profile of the Ob-Ugric passive construction suggests that the landing site of NP-movement is a position with both A and A-bar features. Ob-Ugric NP-movement is A-movement in as much as it feeds case assignment, and it is obligatory (satisfying the EPP). At the same time, it is A-bar movement in as much as it is dedicated to a particular scopediscourse interpretive property. A further criterion of A-bar movement is that its landing site is a so-called criterial position with a freezing effect. The Eastern Mansi subject satisfies this criterion, as well: it cannot move any further. Mansi has no wh-movement; it is a wh-in-situ language - see $(4 a-c)$. Its relative clauses are non-finite prenominal gap relatives with no relative pronoun, e.g.:

$$
\begin{aligned}
& \text { sa:x lia:l wont-əm } \quad \mathrm{k}^{\mathrm{w} a} \text { :rx pøw } \\
& \text { heat against sit_down-PTCP.PST crow nestling } \\
& \text { 'a crow nestling which sat down in the sunshine' }
\end{aligned}
$$


Furthermore, Mansi has no subordinate constructions that could harbor cross-clausal subject movement; it has no raising, and no long topicalization.

\subsection{Fusion of the object and secondary topic roles}

Eastern Mansi also displays a fusion of the object and secondary topic roles, as argued by Virtanen $(2014,2015)$. The term 'secondary topic' has been introduced into Uralic syntax by Nikolaeva (2001). It denotes the lower topic in the sentence structure with two topicalized constituents. In Eastern Mansi, the higher, primary topic slot is only accessible to the subject, and the lower, secondary topic slot is only accessible to the object. Discourse-new, non-presuppositional objects are VP-internal caseless constituents, eliciting no agreement (11a). Discourse-old, topical objects are extracted from the VP into a topic position below the position of the subject-topic, where they participate in verbal agreement, and receive an accusative morpheme (-mø, -m, or -øm) - see (11b) (Riese 2001; Skribnik 2001; Virtanen 2014). Singular and plural 1st and 2nd person pronominal objects bear special allomorphs of the accusative morpheme that are non-distinct from possessive agreement suffixes sharing the person and number of the pronominal stem (Kulonen 2007: 87). ${ }^{4}$ The object agreement suffix on the verb, encoding the number of the object, precedes the subject agreement suffix encoding the number and person of the subject. In the examples below, the gloss of object agreement spells out the singular, dual, or plural number of the cross-referenced object, while the gloss of subject agreement spells out the person and number of the cross-referenced subject. When subject and object agreement appear in a portmanteau morpheme, they are separated by the symbol $<$. For perspicuity's sake, the objects and the object agreement suffixes will be spellt in bold letters, and the accusative morphemes and the object agreement suffixes will also be underlined.

Compare (11a) and (11b), cited from Virtanen (2014). As she established on the basis of the contexts of these sentences, the caseless object of (11a), eliciting no verbal agreement, occurs for the first time in the text. The case-marked object in (11b), triggering agreement on the $\mathrm{V}$, on the other hand, is discourse-old.
a. Kom jowt-nyõõl wø-s.
man bow-arrow take-PST.3sG
'The man took a bow and an arrow.'

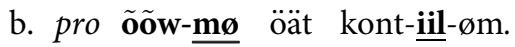
door-ACC NEG find-SG-1SG
'I don't find the door.'

(EM, Virtanen 2014: 407)

(EM, Virtanen 2014: 405)

The claim that agreeing objects in the Ob-Ugric languages are presuppositional topics, whereas non-agreeing objects are part of the domain conveying new information was first made by Nikolaeva on the basis of Northern Khanty (NK) data (1999, 2001; see also Dalrymple \& Nikolaeva 2011), and it has been confirmed by Skribnik (2001) and Sipöcz (2015) with respect to Northern Mansi, and by Virtanen $(2014,2015)$ with respect to Eastern Mansi. Nikolaeva studied an Ob-Ugric dialect which has lost the accusative suffix, so she only focussed on the role of

${ }^{4}$ É. Kiss (2020b) proposes a diachronic explanation of this fact; see also footnote 16. 
object-verb agreement. She analyzed a corpus of more than a thousand transitive clauses, and also worked with informants - hence she could also obtain negative judgments, which is impossible in the case of Eastern Mansi. Her claim that agreeing objects are preposed topics whereas non-agreeing objects are part of the VP, the domain of new information, is based on the different interpretation and the different licensing conditions of the two object types.

Nikolaeva found that only a referential and specific object can elicit agreement. An object represented by a wh-phrase, or an existential or negative quantifier does not leave the VP, and the verb does not agree with it:

$$
\begin{aligned}
& \left({ }^{*} \text { mola }\right) \text { ńa:wre:m-l-am mola we:r-1-ət } /{ }^{*} \text { we:r-l-əlal? } \\
& \text { what child-PL-1SG what do-PRS-3PL/do-PRS-SG<3PL } \\
& \text { 'What are my children doing?' }
\end{aligned}
$$

(NK, Nikolaeva 2001: (18))

Referentiality, and specificity in the epistemic sense are necessary but not sufficient conditions of object-verb agreement; the object must also be discourse-old (13a). Object-verb agreement is impossible in sentences answering the questions What happened? or What did $\mathrm{x}$ do? - whether the object is indefinite, or definite preceded by a demonstrative (13b).

a. What did you do with this reindeer?

Ma tam kalan *we:l-s-əm /we:l-s-e:-m.

I this reindeer kill-PST-1SG/kill-PST-SG-1SG

'I killed this reindeer.'

(NK, Nikolaeva 2001: (14))

b. What happened?

Ma tam kalan we:l-s-em /*we:l-s-e:-m.

I this reindeer kill-PST-1sG/kill-PST-SG-1SG

'I killed this reindeer.'

(NK, Nikolaeva 2001: (30))

Object-verb agreement is obligatory in sentences where a constituent other than the object is narrow focus, whereby the object is necessarily part of the presupposition. The VP-external position of the object is shown by the fact that it precedes the locative adjunct.

$$
\begin{aligned}
& \text { Ma ta:lex ta:ta *a:ket-l-em /a:ket-l-e:-m anta to:ta. } \\
& \text { I mushroom here collect-PRS-1sG/collect-PRS-SG-1SG not there } \\
& \text { 'I collect mushrooms here, not there.' }
\end{aligned}
$$

(NK, Nikolaeva 2001: (32))

When analyzing the sentece structure of Eastern Mansi, which has no speakers any more, Virtanen (2015) could only rely on corpus data. She examined more than 2000 active or passivized transitive clauses, and she found the same pattern of object-verb agreement that was identified by Nikolaeva in Khanty - except that in Eastern Mansi, an object-topic is marked not only by verbal agreement but also by an accusative case morpheme. Thus a non-referential and/ or non-specific object, e.g., a noun phrase introducing a new referent (11a), or an indefinite in the scope of negation (15) is always caseless, and the verb does not agree with it: 


$$
\begin{aligned}
& \text { pro nee öät uusyøntöäl-i. } \\
& \text { woman NEG see-3sG } \\
& \text { 'He does not see any woman.' }
\end{aligned}
$$

(EM, Virtanen 2014: 407)

Definiteness is not sufficient to license accusative marking and agreement; discourse-new definite objects, e.g., the possessive constructions in (16a,b), and the noun phrase with a unique referent in (16c) are caseless and trigger no agreement:
a. pro Ton $\mathrm{k}^{\circ}$ än-pöäl-nø
seemøl-nyoxøs, såjrøng-nyoxøs jälp-øng
DEM out-side-LAT
black-sable
white-sable
sacred-ADJ
toågl-äät nok-posyg-øs.
cloth-3sG up-pull-PST.3sG
'He put his sacred costume of black sable, of white sable on top of that.'

(EM, Virtanen 2014: 409)

b. pro woj-ə kæn røæut-i:-mən, pro sos-ə kæn njøæk-i:-mən ${ }^{5}$ game-3sG field smash-PRS-1DU elk-3sG field stomp-PRS-1DU

'We smash the game's field, we stomp the elk's field.'

(OUDB EM 1569)

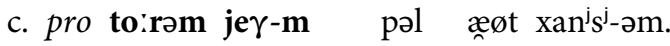

god father-1SG EMPH NEG know-PRS.1SG

(OUDB EM 1569)

The information-structural role and the morphosyntax of the object change in parallel in the course of discourse. When the object introduces a new referent, as in the first clauses in (17a) and in (17b), it is caseless, and triggers no verbal agreement. In the subsequent clauses, the same (by now familiar) referent is denoted by a pronominal object, eliciting agreement. The Ugric languages tend to drop pronouns cross-referenced by agreement suffixes. In the 2 nd and 3 rd clauses of (17a), and in the 2 nd clause of (17b), we attest both subject and object pro-drop.

a. pro toonøtäätøl såjrøng påly-låpsyøx sågrøp-øs, pro pro kånsiit-øs-tø

(he) then white wood-chip carve-PST.3SG (he) (it) mark-PST-SG<3sG

pro pro täärømäät-øs-tø.

(he) (it) drop-PST-SG $<3 \mathrm{SG}$

'Then he carved a white chip of wood, marked it and dropped it.'

(EM, Virtanen 2014: 404)

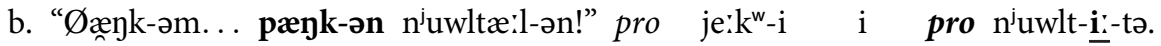
daughter-1sG head-2sG sway-IMP.2sG (she) dance-3sG and (it) sway-sG-3sG

، "My daughter, ... sway your head!" She dances and sways it.'

(OUDB 1559)

Object-topics occupy a position that follows the subject-topic and can also follow clausal adjuncts (18a), but precedes VP-adjuncts $(18 \mathrm{~b}, \mathrm{c})$ :

\footnotetext{
${ }^{5}$ The 3SG agreement suffix attached to a nominal can have the function of a definite determiner in Ob-Ugric (Kálmán 1976a, b; Nikolaeva 2003; É. Kiss and Tánczos 2018). The 3sG suffixes in (16b) have a non-possessive, determining role, i.e., woje means 'the game', and sose means 'the elk'. The possessive relation between the lexical possessor and its possessum is unmarked.
} 
a. Näg nän pøl öänøm tow keet-øs-1-øn?

you why PRT me there send-PST-SG-2SG

'Why did you send me there?'

(EM, Virtanen 2014: 406)

b. pro sos-mø uus köält-øs-tø.

moose-ACC again frighten-PST-SG $<3$ SG

'He frightened the moose again.'

(EM, Virtanen 2014: 406)

c. pro wisy-kom-mø älg-øtään nyerømt-øs-tø.

young-man-ACC up-3SG.LAT pull-PST-SG $<3$ SG

'She pulled the young man up to her.'

(EM, Virtanen 2014: 406)

The floating quantifier construction in (19), where the object-oriented quantifier follows the object-topic, also supports the assumption that the agreeing, case-marked object occupies a VPexternal derived position. Whether the floating quantifier is a stranded determiner in the base position of the object, or an adverb adjoined to VP, its placement after the VP-external object is predicted. ${ }^{6}$

$$
\begin{array}{lll}
\text { pro jiiw-ty-mø } & \text { sok juw-tåtø-s-te } \\
\text { wood-PL-ACC } & \text { all home-bring-PST-SG }<3 \text { SG }
\end{array}
$$

'He brought all the wood home.'

(EM, Virtanen 2014: 392)

\subsection{The secundative construction}

Further evidence of the fusion of the secondary topic and object roles is provided by the fact that in Eastern Mansi, and in the Ob-Ugric languages, in general, the oblique argument of a ditransitive verb can only be topic if it is promoted to object in a so-called secundative construction (Virtanen 2015; see also Skribnik 2001, Sipőcz 2015, 2016; Bárány 2018a). In the alternative directive construction, the theme is a caseless object, and the recipient bears lative case. The directive alignment is the only possibility if the recipient is discourse-new or is a narrow focus, as in (20a). In the secundative alignment, the recipient is the object, and the theme bears instrumental case (20b). In (20b), like in all the active secundative examples of the annotated databases of Eastern Mansi, the recipient object is a [+referential, +specific] element, which acts as a secondary topic eliciting verbal agreement.

${ }^{6}$ The accessible data of this extinct language contain no minimal pair demonstrating the conditions of quantifier float; however, Nikolaeva (1999: 66) provides a minimal pair from the closely related Northern Khanty. In (i), the floating quantifier can either be left-adjacent to the topicalized object, or can follow it. In (ii), containing a non-agreeing, VPinternal object, the only quantifier position is that left-adjacent to the object.

(i) Luw (asa) a:n-ət (asa) il pa:jət-s-əlli.

he all cup-PL all down drop-PST-SG $<3$ SG

'He dropped all the cups.'

(ii) Luw asa a:n-ət (*asa) il pa:jət-əs.

he all cup-PL all down drop-PST.3sG

'He dropped all the cups.' 
$\begin{array}{llllll}\text { a. } & \text { om } & \text { kurøm lyoxx } & \text { äk } & \text { näg-nöän } & \text { tåt-s-øm } \\ \text { I } & \text { three } & \text { message } & \text { only } & \text { 2sG-LAT } & \text { bring-PST-1SG }\end{array}$ 'I brought three messages just for you.'

(EM, Virtanen 2015: 150)

b. pro pro æjn-əl wøær-s-təo, te:n-əl wøær-s-tô.

(she) (he-ACC) drink-INS make-PST-SG $<3$ SG food-INS make-PST-SG $<3$ sG

'She made him drink, she made him food. [She provided him with...]'

(OUDB EM 1527: 200)

The recipient can be primary topic if it is constructed as the object in a secundative construction, and the structure is passivized:

$$
\begin{aligned}
& \text { pro nee-tään } \quad \text { jår-øl mäj-w-øs } \\
& \text { woman-3sG.LAT }
\end{aligned}
$$

The question arises how to analyze secundative ditransitive constructions; whether the secundative alignment is to be derived from the directive alignment transformationally, or ditransitive verbs are associated with two distinct argument realization patterns in the lexicon. The relation of the two alignments is similar to the relation of the English double object construction and the oblique dative form, hence accounts of the latter can be extended to the former. According to Larson (1988) the double object and the oblique dative are alternative constructions derived from the same underlying structure. The oblique dative construction preserves the underlying hierarchy of arguments, whereas the double object construction involves the NP-movement of the dative argument to the specifier of a higher projection. The prevalent accounts of the English dative shift base-generate both variants. According to the Uniform Multiple Meaning Approach, the oblique dative and the double object versions of an English ditransitive verb phrase are two distinct argument structures with different meanings; the former expresses caused motion, the latter expresses caused possession (Harley 2003; Beck \& Johnson 2004; Levin 2008). Rappaport Hovav and Levin (2008) argue that in the case of give-type verbs, the difference of the two alignments lies in information structure: the oblique dative variant is used when the recipient is new information, and the double object variant is used when the recipient is given, topical. Topical elements precede focal elements in the default case. The dative shift/secundative pattern evolved in languages with a rigid word order to allow human, familiar recipients to appear in the topic domain. In the case of Eastern Mansi, there are no more informants to be asked about semantic differences, but reports from Eastern Khanty informants point out a meaning difference between the directive and secundative alignments similar to that observed in English (Sosa 2017: 111). The motivation for the use of the secundative alignment identified by Rappaport Hovav and Levin (2008) is also clearly present in Eastern Mansi. Crucially, neither the multiple meaning approach, nor Rappaport Hovav and Levin's single meaning account compels us to assume a derivational relation between the two Eastern Mansi structures.

The data surveyed in Sections 3.2 and 3.3 indicate that object preposing, similarly to subject movement, has both A-movement and A-bar movement properties in Eastern Mansi. It is Amovement in as much as it feeds case assignment - even if it is not movement for case. (If it 
were motivated by the lack of case, it would affect all objects.) It is A-bar movement in as much as it is movement to a position associated with a scope-discourse interpretive property (topichood), and it only targets referential and specific constituents matching the requirements of this discourse function. It is a criterial position for object topics, involving freezing, i.e., blocking further movement.

\subsection{Sentence structure}

The simultaneous presence of both A and A-bar properties has been pointed out in subjects in Italian and various other languages, as well, by Rizzi (2006) and Rizzi and Shlonsky (2007). In these languages, the movement of the subject from its thematic position is not only A-movement for Case, motivated by requirements of the syntax-morphology interface, but also A-bar movement because it endows the subject with a special discourse property (topic, or subject-ofpredication, role). Further evidence of the A-bar status of the subject is that it occupies a position with a criterial freezing effect, blocking further movement.

Rizzi associates the A- and A-bar properties of the moved subject with separate chain-links: the subject obtains Case in Spec,TP, and it assumes topic function in the specifier of a higher projection called SubjP. In Eastern Mansi, however, there is no reason to presume that case and topic function are assigned in different positions; both are associated with the highest projection of sentence structure, to be labeled as SubjP.

The object-topic of the Eastern Mansi sentence has a similar dual character, obtaining both case and topic function simultaneously; hence it seems plausible to analyze its landing site as the specifier of an ObjP projection, a position with both A- and A-bar properties. The claim that the subject-topic and the object-topic fill the specifiers of two distinct projections is supported by examples like (18a), where an adjunct intervenes between them. (In the Ob-Ugric languages, wh-pronouns appear in situ. In (18a), the interrogative pronoun nän 'why', adjoined to ObjP, appears in the position of a sentence adverbial.)

In view of these considerations, the Eastern Mansi sentence is assigned the following structure:

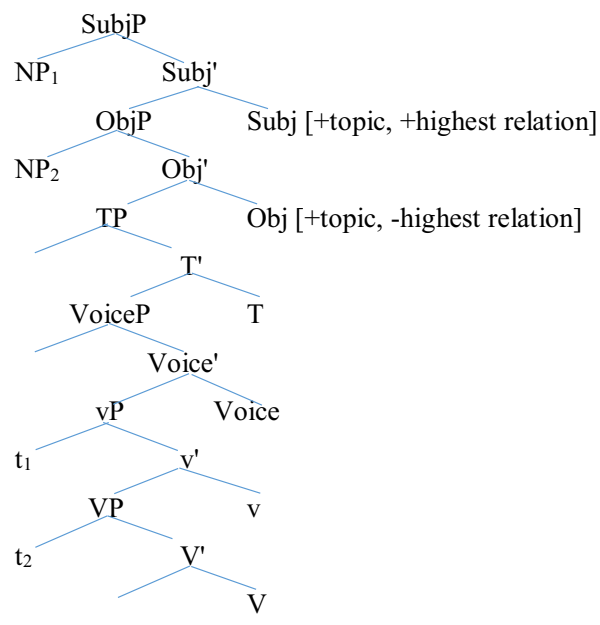


Theta roles are assigned within the vP. The Voice head is either active or passive. An active Voice selects a thematically complete verb phrase, whereas a passive Voice head (akin to Buering's (2013) Pass) selects a verbal projection (vP or VP) whose thematically highest argument is existentially bound but syntactically unrealized. The Obj and Subj heads both have a [+topic] feature (a bundle of the features [+referential] and [+specific]). They assign their topic feature to the constituents in Spec, ObjP and Spec,SubjP, which value their phi features. The filler of Spec,Obj values the number feature of Obj, and the filler of Spec,SubjP values the person and number features of Subj. Obj and Subj are manifested as agreement suffixes on the verb.

Spec, ObjP is not accessible to the subject, which follows from the [-highest relation] feature of Obj. Subj is specified as [+highest relation]. (The [+/-highest relation] feature also plays a role in Kiparsky's (2001) analysis of the case system of Finnish, another Uralic language.) SubjP shows an EPP effect (in passivized presentative sentences such as (7), Spec,SubjP may be filled by a spatiotemporal expletive).

As object agreement goes hand-in-hand with accusative assignment, and subject agreement goes hand-in-hand with nominative assignment in Eastern Mansi, case assignment could be regarded as a result of agreement. This move, however, would have the consequence that VPinternal, discourse-new objects remain caseless, i.e., the Case Filter has to be given up. The lack of case on VP-internal objects cannot be attributed to the incorporation or pseudo-incorporation of the object because the caseless object is often clearly referential - as was illustrated in (16a-c).

The Case Filter can be maintained if we account for the distribution of case in the framework of dependent case theory (Marantz 1991; Baker 2015). vP and SubjP represent two phases, hence two spellout domains, for case assignment. If the object, $\mathrm{NP}_{2}$, is discoursenew, $\mathrm{NP}_{2}$ and $\mathrm{NP}_{1}$ get cases in separate domains: $\mathrm{NP}_{2}$ in the $\mathrm{VP}$, and $\mathrm{NP}_{1}$ in Subje, and each of them is assigned unmarked case. If $\mathrm{NP}_{2}$ is topic-moved into Spec, ObjP, both NPs are assigned case in the higher domain; $\mathrm{NP}_{1}$ gets nominative, and $\mathrm{NP}_{2}, \mathrm{c}$-commanded by $\mathrm{NP}_{1}$, gets accusative. If the Spec, SubjP position of an intransitive sentence is filled by the NPmovement of an inherently case-marked constituent, the nominative assigned in Spec, SubjP overwrites the inherent case.

Morphological evidence (e.g., the preservation of the Proto-Uralic - $m$ accusative suffix) suggests that Eastern Mansi represents the most conservative dialect of the Ugric languages (Abondolo 1998). Syntactic reconstruction led to the same conclusion. É. Kiss (2020a) adopted the comparative method to syntax, forming correspondence sets from syntactic elements. The comparison of the Ugric languages has shown that SOV word order, the fusion of discourse roles and grammatical functions, and the marking of topical objects by object agreement on the verb and by accusative case on the object represent Proto-Ugric heritage in Eastern Mansi.

\subsection{Interim summary}

Agreement and structural case assignment go hand-in-hand in Eastern Mansi: the subject and the object get nominative and accusative case, respectively, if and only if they elicit agreement on the verb. The correlation of case and agreement must be due to the dual functions that the agreeing subject and object fulfill. As argued by Givón (1975: 185) on the basis of a wide variety of languages, among them emerging languages such as child language and Creol languages, "grammatical agreement is fundamentally a topic related phenomenon, arising from anaphoric 
pronominalization in topical discourse contexts. ${ }^{7}$ The diachronic rise of grammatical agreement from pronouns, as well as many synchronic functions universally characteristic of grammatical agreement, cannot be explained otherwise. This is not to say that a system, once established, cannot change independently of its point of origin ... Our fundamental understanding of the synchronic phenomenon, however, could not be separated from our understanding of its natural diachronic origins. For in a number of subtle ways, those origins persist ..." Whereas the fundamental role of agreement is to cross-reference the topic in the verb phrase, the function of structural case is to mark the relative prominence of a noun phrase in the thematic hierarchy of arguments. Case and agreement correlate in Eastern Mansi because they target the same structural level.

\section{PARTIAL INDEPENDENCE OF CASE AND AGREEMENT: EASTERN AND NORTHERN KHANTY, AND NORTHERN MANSI}

\subsection{The loosening of word order}

In most of the extant Khanty and Mansi dialects, SOV word order and the fusion of discourse roles and grammatical functions is still a strong tendency, but the influence of Russian has loosened their strict correlation; presentative VS (23a), as well as SVX (23b) and SVO (23c) orders have also appeared - see Nikolaeva (1999: 57) on Northern Khanty; Csepregi (1997, 2019) and Asztalos, Gugán, and Mus (2017) on Eastern (Surgut) Khanty; and Riese (2001: 69) on Northern Mansi. According to Asztalos et al. (2017), the proportion of sentences with postverbal constituents is $8-9 \%$ both in Eastern Khanty records from the beginning of the 20th century and in contemporary Eastern Khanty texts. What has changed is the function of the postverbal elements; whereas in the old texts, they are topical afterthoughts clarifying the content of the sentence by spelling out a dropped pronoun, an implicit participant or a spatiotemporal element, in the modern texts, the majority of postverbal elements convey new information; they are part of the predicate phrase. For example:

a. U:-s-yən ime:-yən ike:-yən.

live-PAST-3DU old_man-DU old_woman-3DU

'There lived an old man and an old woman.'

(NK, Nikolaeva 1999: 57)

b. Taw tinal-as-te ēka-te $\chi$ on wańka-n.

he sell-PAST-SG $<3$ SG wife-3SG belly Vanyka-LAT

'He sold his wife to pot-bellied Vanyka.'

(NM, Kálmán 1976a: 77)

c. pro ŏjəyt-əm məta puləli.

find-PST.1sG some piece

'I found some piece [of gold].'

(EK, Asztalos et al. 2017: 43)

${ }^{7}$ Dalrymple and Nikolaeva (2011) make a similar claim about object-verb agreement in Differential Object Marking languages. 
These facts suggest that the rigidly SOV word order determined by structure (22) is slowly giving way to a more flexible, SOV/SVO word order, a mixed type, in these languages.

In Northern Khanty, Eastern Khanty, and Northern Mansi, the roles 'subject' and 'primary topic' are still mostly fused, often via passivization. A non-referential and/or non-specific underlying subject is demoted, and the highest referential and specific argument (whether a theme, a goal, or a locative) undergoes NP-movement (see Kulonen 1989; Nikolaeva 1999, 2001; Skribnik 2001; Sosa 2017, etc.). The subject-topic is assigned nominative case, and elicits agreement on the verb. Object-verb agreement, too, still mostly follows the pattern inherited from Proto-Ugric: the object elicits verbal agreement if it is topic. Accusative marking, however, has become largely independent of agreement.

\subsection{Objects in Eastern Khanty}

In the Surgut dialect of Eastern Khanty, an object represented by a 3rd person pronoun is always case-marked by a - $t$ suffix, the same suffix that marks accusative case in Hungarian - see (24a,b) (Csepregi 1998). Since pronominals refer to contextually or situationally given referents, they are the most common, most likely targets of topicalization of all NP types. The overwhelming majority of Eastern Khanty pronominal objects are indeed topics, however, we also find focal personal pronouns in contrastive contexts (24b). Focal pronouns, though case-marked, trigger no verbal agreement.
a. Vera $\Lambda \ddot{\mathbf{u} w}-\underline{\mathbf{a t}} w \overline{\mathbf{u}}-\Lambda$-to $\underline{\gamma}$.
Vera she-ACC know-PRES-SG $<3$ SG
'Vera knows him/her.'
(EK, Márta Csepregi, fieldwork)
Ma $\lambda \ddot{\text { üw-at }}$ tojəmtə- $\lambda$-əm.
I he-ACC understand-PRES-1SG
b. (We are good friends. He understand me.)
'I understand him.'
(EK, Sosa 2017: 180)

The generalization of accusative marking to all 3rd person object pronouns must have happened recently in Eastern Khanty. Filchenko (2007), describing the most archaic, Vasyugan subdialect of Eastern Khanty (VK), still found "occasional examples" of uncasemarked VP-internal pronominal objects: ${ }^{8}$

\footnotetext{
${ }^{8}$ The archaic features of the Vasyugan subdialect have been pointed out by Gulya (1970), Kulonen (1989), Décsy (1990), and Filchenko (2007: XVI). Filchenko's description of Vasyugan Khanty is based on linguistic material collected in the 1960s and 1970s, and on his own fieldwork between 1997 and 2005 with the remaining 20 elderly Vasyugan speakers, as well as with the less than 300 elderly speakers of the neighboring subdialects of Eastern Khanty.
} 


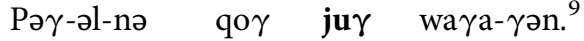

$$
\begin{aligned}
& \text { son-3SG-LOC long she call-PST.3sG } \\
& \text { 'Her son called (for) her for a long time.' }
\end{aligned}
$$

In the case of 1st and 2nd person pronominal objects, accusative marking must be a new development both on VP-internal and on topicalized pronouns. In the system of object marking reconstructed for Proto-Ugric by É. Kiss (2017), based on various fragments of an Inverse Accusative-marking Constraint and an Inverse Agreement Constraint preserved in Hungarian and in some Ob-Ugric dialects, the case-marking of 1st and 2nd person objects and verbal agreement with them are blocked. Versions of these constraints are attested not only in several Uralic languages, among them languages of the Samoyedic branch (Dalrymple and Nikolaeva 2011: 130, 197), but in several non-Uralic languages, as well (Comrie 1980; Bobaljik and Branigan 2006; Béjar and Rezac 2009; Bárány 2015, 2018a, b; etc.). ${ }^{10}$ É. Kiss $(2013$; 2017) analyzed the two constrains as manifestations of an Inverse Topicality Constraint, forbidding that the structural hierarchy of topic constituents contradict the hierarchy of their referents in a so-called Animacy (Comrie 1980) or Topicality (Moravcsik 1974; Givón 1975), or Person Hierarchy (Silverstein 1976; Dixon 1994). The Animacy/Topicality/Person Hierarchy ranks referents on the basis of their activity in a discourse situation, namely:

$$
\begin{aligned}
& \text { Animacy/Topicality/Person Hierarchy } \\
& 1 S G>1 P L>2 S G>2 P L>3 S G>3 P L
\end{aligned}
$$

3rd person participants can be further ranked, for example, with animate referents preceding inanimate ones. Languages tend to collapse this articulated hierarchy into a three-grade or twograde scale (Comrie 1980). Eastern Khanty has only preserved the Inverse Agreement Constraint. Based on a two-grade animacy scale (1st/2nd person $>3 \mathrm{rd}$ person), the constraint blocks the assignment of the [+topic] feature to 1 st and 2 nd person object pronouns, i.e., it blocks their topicalization. Though we can still find caseless 1 st and 2nd person objects in Vasyugan texts sporadically (27), the majority of them are accusative-marked (28a,b). Crucially,

${ }^{9}(25)$ has a locative subject. So-called locative subjects occur in all dialects of Khanty, and are most frequent in the Vasyugan dialect. They have been mistakenly analyzed as ergative subjects (Gulya 1970; Baker 2015); however, their locative case is optional, and they occur with transitive and unaccusative verbs, as well:

(i) Qu-jali-nə aj ni tfupi-1-tə. man-DIM-LOC small woman kiss-PRS-SG $<3$ SG 'The young man is kissing a young woman.'

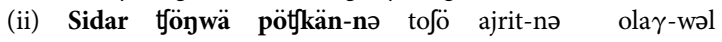
Sidor late gun-LOC also canoe-LOC lie-PRS.3sG 'Late Sidor's gun also lies in the canoe.'

(VK, Filchenko 2007: 398)

(VK, Filchenko 2007: 415)

As shown by Filchenko (2007) and Sosa (2017), locative subjects function as recurring topics in topic shift contexts. I assume that they are adjuncts, the equivalents of the English As for ... phrases, and the real subject in these sentences is a pro in Spec,SubjP.

${ }^{10}$ The Inverse Accusative-assignment Constraint is related to the Person-Case Constraint; whereas the former controls the relation of topics in the CP-domain, the Person-Case Constraints of various European languages control the relation of internal topics (É. Kiss 2017). 
however, 1st and 2nd person objects - whether caseless or case-marked - never elicit verbal agreement:

$$
\begin{array}{llll}
\text { Mä noy qitfk-ali-natł } & \text { utł } \gamma \ddot{a}-1-\partial m \\
\text { I } & \text { you knife-DIM-COM } & \text { cut-PRS-1sG } \\
\text { 'I will cut you with a knife' } &
\end{array}
$$

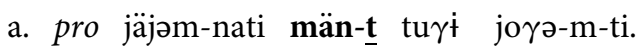 axe-COM I-ACC away chop-MOMENT-3SG
'He will chop me with an axe.'

(VK, Filchenko 2007: 114)

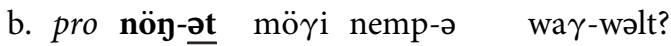
you-ACC what name-INSTR call-PRES.3PL

'By what name do they call you?'

(VK, Filchenko 2007: 114)

In contrast to pronominal objects, objects represented by lexical noun phrases are always caseless in Eastern Khanty, whether they are discourse-new with no verbal agreement (29a) or topical, eliciting agreement (29b).

\section{a. pro ənə $\lambda$ sårt wä- $\lambda$.}

big pike kill-PRES.3SG

'She kills a large pike.'

(EK, Sosa 2017: 103)

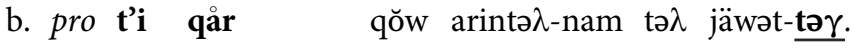
this reindeer.bull long aim-APPR full shot-PAST.SG $<3$ SG 'He shot this reindeer bull from far away.'

(EK, Sosa 2017: 156)

Like in Eastern Mansi, object-verb agreement is licensed by the [+topic] feature of the object. Referentiality and definiteness are not sufficient; the object must also be discourse-given for agreement to appear. In the secundative construction in (30), the definite recipient is presented as new information, hence it does not trigger agreement:

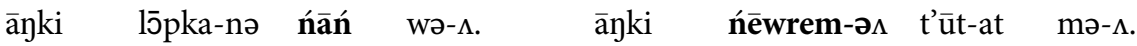

$$
\begin{aligned}
& \text { mother shop-LOC bread buy-PRS.3SG mother child-3sG that-INS give-PRs.3sG } \\
& \text { 'The mother buys bread in the shop. The mother provides her child with that.' } \\
& \text { (EK, Typological Database of the Ugric Languages) }
\end{aligned}
$$

In sum: accusative marking does not depend on the discourse function of the object in Eastern Khanty any more; pronominal objects are always case-marked (except for sporadic archaisms), whereas lexical objects never bear an overt accusative morpheme. At the same time, object-verb agreement continues to be elicited by the [+topic] feature of the object. These facts indicate that Eastern Khanty has severed accusative marking from object topicalization. The distribution of the allomorphs: $-t$ on personal pronouns, and zero elsewhere, still reflects the former discourse 
motivation of accusative assignment: inherently topical pronominal objects are the ones that bear a visible accusative suffix, and lexical objects, introducing a new referent in the majority of cases, are the ones that are seemingly caseless.

The Khanty clause structure is similar to the Mansi clause structure represented in (22). ${ }^{11}$ In this structure, however, $\mathrm{vP}$ and SubjP do not represent two separate domains for case assignment any more; the subject and the object are assigned case in the same domain whether the object is in Spec, ObjP, or in Spec,VP. The subject receives unmarked nominative case, and the object, c-commanded by it, assumes dependent accusative.

\subsection{Objects in Northern Khanty}

Pronominal objects are always case-marked in Northern Khanty, as well - but they bear special allomorphs that are identical with the morphemes of the possessive agreement paradigm (for a diachronic explanation of this fact, see É. Kiss 2020b). Pronominal objects bear the same possessive-accusative endings whether they are VP-internal with no verbal agreement (31a), or they are in topic position, eliciting agreement (31b).

$$
\begin{aligned}
& \text { a. Ma nay-e:n wa:n-s-əm. } \\
& \text { I you-ACC see-PAST-1SG } \\
& \text { '(Who did you see?) I saw you.' } \\
& \text { b. Ma nay-e:n wa:n-s-e:-m. } \\
& \text { I you-ACC see-PAST- SG-1SG } \\
& \text { '(Did you see me?) I saw you.' }
\end{aligned}
$$

(NK, Nikolaeva 1999: 65)

(NK, Nikolaeva 1999: 65)

Objects represented by lexical noun phrases receive no morphological marking either in topic or in VP-internal position, but in topic position they trigger verbal agreement:

$$
\begin{aligned}
& \text { Luw tam kalay ńu:xəl-sə-lli. } \\
& \text { he that reindeer follow-PAST-SG<1SG } \\
& \text { 'He followed that reindeer.' }
\end{aligned}
$$

The facts surveyed so far display a situation similar to that attested in Eastern Khanty: accusative marking is generalized to all objects, with overt accusative morphemes on pronouns and null accusative morphemes on lexical noun phrases - as opposed to object-verb agreement, which is still licensed by the topicality of the object. In Northern Khanty, however, a sign of the dissociation of object-verb agreement and object-topicality has also appeared. As shown by Dalrymple and Nikolaeva (2011: 148-149), the recipient of a secundative construction, and the

\footnotetext{
${ }^{11}$ In fact, the order of the passive and tense morphemes is reversed in Khanty, with the passive suffix sandwiched between tense and object agreement - as shown in (i). This might be due to morphophonological metathesis.

(i) śij oxət-s-a:j-uw.

FOC come-PST-PASS-1PL

'(Somebody) came to us.'
} 
causee argument of a causative construction always elicit agreement whether or not they are [+referential, +specific]. E.g.:

\author{
Xoj xo:llə-ptə-s-lii? \\ who cry-CAUS-PST-SG $<3$ SG \\ 'Whom did he make cry?'
}

(NK, Dalrymple and Nikolaeva 2011: 149)

Apparently, the movement of recipient and causee objects to Spec,ObjP has grammaticized in Northern Khanty.

In sum: Northern Khanty, like Eastern Khanty, has generalized accusative marking from topical objects to all objects. The accusative morpheme has a phonologically null allomorph on lexical noun phrases, and special overt allomorphs on personal pronouns represented by possessive agreement suffixes of the same person and number as the pronominal stem. At the same time, agreement depends on whether the object has been raised to Spec, ObjP. In Northern Khanty, recipient objects - whether definite or indefinite - always trigger verbal agreement; apparently, their movement to Spec, ObjP is obligatory. ${ }^{12}$

\subsection{Objects in Northern Mansi}

Northern Mansi object marking is similar to Northern Khanty object marking in most respects. Personal pronouns bear accusative morphemes which are non-distinct from possessive agreement suffixes of the same person and number as the pronominal stem (Kálmán 1976a, b). Northern Mansi pronominal objects bear such possessive-accusative suffixes whether they are non-agreeing carriers of new information inside the VP as in (34a), or they are agreeing topics (34b).

a. $\chi \bar{u}$ rum lūnt jo $\chi \mathrm{t}-\mathrm{s}-\partial \mathrm{t} \quad$ os taw-e kins-ē $\gamma$-ət.

three goose come-PAST-3PL and he-ACC search-PRES.3SG

'Three wild geese appeared and look for him.'

(NM, Skribnik 2001: 226)

b. Am taw-e mōjt-əl mōjt-i-1-1-um.

I he-ACC tale-INSTR tell-PRES-SG $<1$ SG

(NM, Skribnik 2001: 228)

Whereas pronominal objects are always case-marked, objects represented by lexical noun phrases never bear any visible case ending; their topic status is only encoded by verbal agreement. Compare (35a) and (35b): the non-agreeing focal object in (35a), and the agreeing topical object in (35b) are both caseless. (35a) also illustrates the loosening of the former, strictly SOV word order: the focal object is not immediately preverbal, and there is a postverbal constituent.

\footnotetext{
${ }^{12}$ For the outlines of a syntactic account of the relation of case and agreement in Northern Khanty, based on the assumption that spell-out domains are determined dynamically, see Smith (to appear).
} 
a. Am ōs $\chi \overline{\mathbf{u}}$ rəm sāt sajt nay-ən mī $\gamma$-əm akw' èt ūnl-ən-ən-mā $\gamma \partial s$. I also three hundred rubel you-LAT give-1SG one night sit-NOM-2sG-for 'I also give you 300 rubels for your waking [mourning] for a night.'

(NM, Bíró 2015: 50)

b. pro akw' sup-ä kat'i-tä-n mi-s-tä.

one piece-3SG cat-3SG-LAT give-PAST-SG $<3$ SG

'She gave a piece of it to her cat.'

(NM, Bíró 2015: 50)

In Northern Mansi, similarly to Eastern Khanty but in contrast to Northern Khanty, the recipient object of secundative constructions does not obligatorily elicit object-verb agreement:

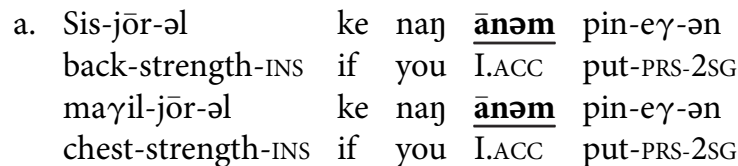

'If you provide me with back-strength, if you provide me with chest-strength'

(NM, Bíró \& Sipőcz 2017: 48)

b. jay-əm sēl-əm ōln-nəl akw ōln-pāl-əl ānəm at majl-əs. father-1SG gather-PTCP money-ABL one money-half-INS $\overline{\text { I.ACC }}$ NEG give-PST.3sG 'He did not give me even a half penny from the wealth gathered by my father.'

(NM, Bíró \& Sipöcz 2017: 48)

Bíró and Sipöcz (2017) observe that in their Northern Mansi database, the recipient objects that fail to elicit verbal agreement are all objects that are of a higher person than the subject, and they raise the possibility that this is a consequence of the Inverse Agreement Constraint. However, they also have both monotransitive $(37 \mathrm{a}, \mathrm{b})$ and ditransitive examples $(37 \mathrm{c})$ where an object that is of a higher person than the subject elicits agreement, which provides evidence against the hypothesis that the Inverse Agreement Constraint is active in Northern Mansi:

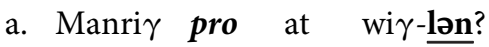

Why (me) NEG take-PRS.SG<2SG

'Why do you not take me?

(NM, Bíró \& Sipőcz 2017: 49)

b. Taw nayən erupt-i-te.

(s)he you.ACC love-PRS-SG<3sG

'(S)he loves you.'

(NM, Bíró \& Sipőcz 2017: 49)

c. Am nayən sūp-əl junt-i-ləm.

I you.ACC shirt-INS sew-PRS-SG $<1$ SG

'I sew a shirt for you.'

(NM, Bíró \& Sipőcz 2017: 49) 
Recapping the relevant properties of Northern Mansi: accusative marking has become independent of discourse functions in Northern Mansi, as well. All pronominal objects bear overt accusative markers, which are non-distinct from possessive suffixes (similarly to Eastern Mansi see footnote 4, and to Northern Khanty). The accusative marker of lexical objects, by contrast, is always null. Generalized accusative marking indicates that vP and SubjP form a shared domain for case assignment: whether the object of a transitive construction is in Spec,VP, or in Spec, ObjP, it is c-commanded by the subject in Spec, SubjP, and receives dependent accusative. At the same time, agreement is only elicited if the object has been raised to Spec, ObjP.

\subsection{Interim summary}

Eastern Khanty, as well as Northern Khanty and Northern Mansi still preserve the correlation of nominative case and subject-verb agreement. This must be a consequence of the fact that the subject of these languages, nearly always occupying the specifier of a SubjP projection, still fulfills a dual, subject-topic role. Although Nikolaeva (1999) reports the occurrence of presentative VS orders in the Russified speech of the younger generations, such sentences are still exceptional. The parallelism of accusative marking and object-verb agreement, on the other hand, is disappearing, which must be due to the fact that objects and oblique complements more and more often appear in non-canonical positions, e.g., in SVO and SVX orders. Object agreement on the verb still encodes the topic function of the object, however, accusative marking has been generalized to all objects. This means in terms of dependent case theory that the subject and the object are always assigned case in the same domain. In terms of Baker (2015: 149), v has become a soft phase head, as a consequence of which the contents of the VP remain active in the SubjP phase. The morphological realization of generalized accusative case (with an overt allomorph on pronouns, and a phonologically empty allomorph on lexical objects) is the fossilization of the two most common syntactic scenarios of the former stage of these languages: pronominal objects functioning as topical, hence case-marked elements, and lexical objects introducing new, hence caseless information.

\section{INDEPENDENCE OF CASE AND AGREEMENT: HUNGARIAN}

Modern Hungarian ( $\mathrm{MH}$ ) has largely adopted the SVO syntax of the neighboring Indo-European languages, but Old Hungarian $(\mathrm{OH})$ still displays relics of the sentence structure reconstructed for Proto-Ugric, represented in (22). Non-finite embedded clauses are still mostly SOV, and often have a caseless (definite or indefinite) object in early Old Hungarian, for example:

$$
\begin{aligned}
& \text { [ợ è gondol-uan] yme vr-nac angal-a ièlen-e-c nèk-i. } \\
& \text { he this think-PTCP lo Lord-DAT angel-3SG appear-PAST-3SG DAT-3SG } \\
& \text { 'He having thought this, the Lord's angel appeared to him.' }
\end{aligned}
$$

(OH, München Codex (1416/1466): p. 8 verso)

At the same time, main clauses, and finite embedded clauses gradually replacing non-finite subordination have shown a 'Topic Focus V XP') order with a case-marked object since the first surviving documents from the late 12th century (É. Kiss 2014). In this sentence structure, the 
discourse functions encoded in the preverbal domain are clearly separate from the thematically motivated argument hierarchy in the postverbal domain:

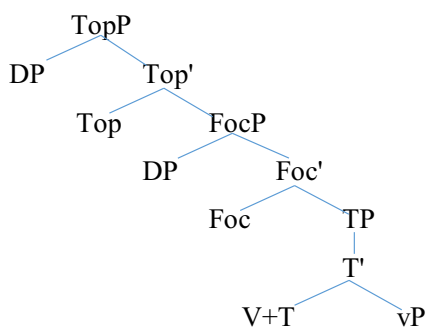

In the Modern Hungarian sentence, topic selection is free, i.e., any and any number of the arguments of the verb can be topicalized. This is not reflected by agreement. The former topicmarking role of agreement has been grammaticized in morphology; the most typical exponents of the topic role, the subject and the definite object, trigger verbal agreement automatically, whatever discourse role they fulfill and whatever structural position they occupy in the sentence.

Since Hungarian morphology has frozen the former, syntactically determined correspondence of the constituent triggering verbal agreement and the argument highest in the thematic hierarchy, nominative case, encoding thematic prominence, still mostly cooccurs with verbal agreement - irrespective of the discourse status of the nominative noun phrase. Nevertheless, we can also attest mismatches sporadically. For example, the contrasted subject of an infinitive is represented by an overt nominative noun phrase, as shown by Szabolcsi $(2005,2007)$ and Bartos (2006):

a. El-kezd-ett

[kevesebb színésznő kap-ni jó kritiká-k-at]. PRT-begin-PAST.3SG fewer actress get-INF good review-PL-ACC 'It began to be the case that fewer actresses overall were getting good reviews.'

b. Szeret-né-1 [nem te len-ni a legmagasabb]? like-COND-2sG not you be-INF the tallest

'Would you like it to be the case that it is not you who is the tallest?'

c. Nem fog-ok [csak én dolgoz-ni éjszaka]. not will-1SG only I work-INF at.night

'It is not going to be the case that only I work at night.'

The following case of nominative without subject-verb agreement may involve an obsolete agreement morpheme merged with the non-finite suffix, that which is present in such dialectal forms as tesz-en 'put-3SG', megy-en 'go-3SG', however, synchronically, it contains a nominative subject and a non-agreeing participial predicate: 
(41) [Péter nem lé-vén otthon] nem tud-t-uk elintéz-ni az ügy-et.

$(\mathrm{MH})$

Peter not be-PTCP at.home not can-PAST-3<1PL settle-INF the matter-ACC

'Peter not being at home, we could not settle the matter.'

In Proto-Ugric, which had no articles, the object elicited verbal agreement if it was a discoursegiven vP-external topic (É. Kiss 2017). Modern Hungarian has replaced the topicality condition of object-verb agreement with a definiteness condition. The [+definite] feature shares the specificity/givenness component of the [+topic] feature, hence the reinterpretation of the [+topic] feature as [+definite] is a fairly common developmental step, attested, for example, in the Luganda language of the Bantu family (Givón 1975: 158). The objects eliciting verbal agreement in Modern Hungarian include object NPs with a definite article, proper names, 3rd person pronouns, possessive constructions, and NPs with an - $i k$ suffix (a partitive suffix, originally crossreferencing a pro-dropped 3 rd person plural possessor) - see (42a,b). (In Hungarian, the object agreement suffix only denotes the person of the object, hence portmanteau object agreement + subject agreement complexes will be glossed by symbols of the type $3<1 \mathrm{sG}$.) The accusative suffix, $-t$, has been generalized to all objects.
a. Mari meg-ír-t-a
a /minden-ik
Mary PRT-write-PAST-3<3SG the/every-PART
dolgozat-ot.
paper-ACC
'Mary wrote the/each paper.'
b. Mari meg-hív-t-a $\quad$ Péter-t /Péter család-já-t /ők-et.
Mary PRT-invite-PAST-3<3SG Peter-ACC/Peter family-POSS-ACC/they-ACC
'Mary invited Peter/Peter's family/them.'

Indefinite objects are case-marked but do not give rise to verbal agreement:

a. Mari dolgozat-ot/dolgozat-ok-at ír-t.

Mary paper-ACC/paper-PL-ACC write-PAST.3SG

'Mary wrote a paper/papers.'

b. Mari ír-t egy/három/néhány/sok dolgozat-ot.

Mary write-PAST.3sG a /three/some /many paper-ACC

'Mary wrote a paper/three/some/many papers.'
c. Mari meg-ír-t minden dolgozat-ot
Mary PRT-write-PAST-3SG every paper-ACC
'Mary has written every paper.'

1st and 2nd person objects, as opposed to 3rd person pronominal objects, do not elicit verbal agreement in sentences with a 3rd person subject (44a,b); what is more, 1st and 2nd person singular objects do not bear the general - $t$ accusative morpheme, either (44a). At the same time, both singular and plural 1st and 2nd person objects bear a morpheme corresponding to the 
possessive suffix of the same person and number as the pronominal stem, as attested in Northern Mansi and Northern Khanty. ${ }^{13}$
a. Péter lát-ott
en-g-em /té-g-ed. ${ }^{14}$
Peter see-PAST.3sg I-EPENTH-1sG/you-EPENTH-2sG
'Peter saw me/you.'
b. Péter lát-ott mi-nk-et /ti-tek-et.
Peter see-PAST.3SG I-1PL-ACC/you-2PL-ACC
'Peter saw me/you.'

The lack of agreement with 1st and 2nd person pronominal objects has been given various explanations. Bartos $(2000,2001)$ claims that only DPs trigger verbal agreement, and 1st and 2nd person pronouns are NumPs. According to Coppock and Wechsler (2012), object-verb agreement is triggered by a formal definiteness feature of the object. They argue that the restriction of agreement to third person objects is a historical relic; the object agreement suffix derives from an incorporated pronoun, and only third person pronouns were incorporated into the verb in the proto-language. Coppock (2013) claims that the formal [DEF] feature of the object is determined by its anaphoricity. First and second person pronouns are [-DEF] because they are not anaphoric but indexical. Rocquet (2013) proposed an account in the framework of nano-syntax. In her theory, the conjugation used with definite objects arises from the spell-out of a structural definiteness layer on the finite verb. This layer is base-generated in definite direct objects. Whereas the definiteness morpheme of 3rd person pronouns is spelled out on the finite verb, 1st and 2nd person pronouns retain their definiteness feature.

Bárány $(2015,2018 b)$ offers an explanation based on the assumption of cyclic Agree (Béjar \& Rezac 2009). In Bárány's approach, a subject, and an object with the feature [+person] value $\mathrm{v}+\mathrm{T}$ together, which is realized as the objective conjugation, involving agreement with both the object and the subject. When the object is 1 st person, having the features [+ person, + participant, + speaker], or 2nd person, having the features [+ participant, +speaker], then a 3rd person subject with the feature [+person] has no feature left to be valued. In such cases, $v$ becomes inactive, and agreement between the subject and $\mathrm{T}$ yields the subjective conjugation.

The explanation proposed by É. Kiss (2017), incorporating ideas of Marcantonio (1985), relates the lack of agreement with 1st and 2nd person objects to the lack of accusative case on 1st and 2nd person singular objects; it analyzes all these phenomena as grammaticized relics of the Inverse Topicality Constraint, which was active at the former SOV stage of the language. The lack of agreement with 1st and 2 nd person objects is a grammaticized consequence of the former ban on inverse agreement, and the lack of accusative marking on 1st and 2nd person objects is a relic of the former ban on inverse accusative marking. Hungarian must have used the articulated Topicality Hierarchy in (45), as agreement with a 1st or 2nd person object is possible if the subject is

\footnotetext{
${ }^{13}$ Den Dikken (2006) analyzes these pronouns as complex possessive structures.

${ }^{14}$ In some substandard dialects, these forms do receive the $-t$ accusative suffix, i.e.:
(i) en-g-em-et té-g-ed-et
I-EPENTH-1SG-ACC YOu-EPENTH-3SG-ACC
'me' 'you-ACC'


1st person, the object is 2nd person (46), or both are 1st person or both are 2nd person, and the subject is singular, the object is plural (47a). When the subject and the object are of the same (1st or 2nd) person but the subject is plural and the object is singular, agreement is blocked (47b).

Topicality Hierarchy in Modern Hungarian

$$
1 \mathrm{SG}>\left\{\begin{array}{c}
1 \mathrm{PL} \\
2 \mathrm{SG}>2 \mathrm{PL}
\end{array}\right\}>3
$$

$$
\begin{aligned}
& \text { Én lát-l-ak té-g-ed /ti-tek-et. } \\
& \text { I see-2-1sG you-EPENTH-2SG/you-EPENTH-2PL-ACC } \\
& \text { 'I see } \mathrm{you}_{\mathrm{sg}} / \mathrm{you}_{\mathrm{pl}} \text { '. }
\end{aligned}
$$

$$
\begin{aligned}
& \text { a. Én mi-nk-et javasl-om /*javasl-ok a feladat-ra. }{ }^{15} \\
& \text { I we-1PL-ACC propose-3 }<1 \mathrm{sG} / \text { propose-1sG the task-SUBL } \\
& \text { 'I propose us for the task.' }
\end{aligned}
$$

b. Mi en-g-em javasol-unk/*javasol-j-uk a feladat-ra.

we I-EPENTH-1SG propose-1PL/propose-3-1PL the task-SUBL

'We propose me for the task.'

The facts surveyed suggest that Hungarian used to be a language of the Eastern Mansi type, with SOV word order, with subject and object topicalization and with topicalized elements eliciting verbal agreement and receiving structural case, and it used to observe the Inverse Topicality Constraint. ${ }^{16}$

${ }^{15}$ In cases like $(47 \mathrm{a}, \mathrm{b})$, where the object and the subject are of the same person but the subject is singular, the object is plural, the default 3rd person object agreement suffix is used.

${ }^{16}$ The question arises why the archaic Eastern Mansi dialect has not preserved traces of the Inverse Topicality Constraint. In fact, it has. Recall that in Eastern Mansi, the allomorphs of the accusative case suffix appearing on 1st and 2nd person pronominal objects are non-distinct from possessives suffixes sharing the person and number of the pronominal stem:

(i) Öänøm jål-ääl-ääl-øn.

I.1sG down-kill-IMP-SG<2SG

'Kill me!'

(EM, Virtanen 2014: (15))

(ii) Om nään jorøl tảt-øs-løm tøg.

I you.2SG on.purpose bring-PST-SG<1SG here

'I brought you here on purpose.'

(EM, Virtanen 2015: 42)

The possessive suffix is also present on 3rd person pronominal objects, however, it can combine with the $-m$ accusative suffix:

(iii) tääw-øtääm

he-3SG.ACC

'him'

(EM, Kulonen 2007: 52)

Pronouns bearing a possessive agreement suffix were originally reflexives functioning as emphatic, strong pronouns denoting discourse-new individuals. The fact that 1 st and 2 nd person objects, unlike 3rd person pronominal objects, never bear the $-m$ accusative suffix is a relic of the Inverse Topicality Constraint. The reinterpretation of the possessive endings of 1 st and 2 nd person pronouns as an accusative morpheme is a later development. Because of the coincidence of the subject and topic roles, subject pronouns were never discourse-new in Eastern Mansi; hence the possessive suffixes never occurred on subject pronouns. Since in the bare pronoun - possessive-marked pronoun (i.e., weak pronoun - strong pronoun) opposition, 1st and 2nd person bare pronouns were always subjects, and 1st and 2nd person possessive-marked pronouns were always objects, the possessive endings of the strong pronouns came to be reanalyzed as accusative allomorphs (É. Kiss 2020b). 
In Modern Hungarian, however, both agreement is severed from discourse roles, and generalized case-marking is independent of information structure. Though the definiteness condition of objectverb agreement is a descendant of the Proto-Ugric topicality condition, definite objects are merely frequent - but by no means obligate - targets of topicalization. Focussed definite objects (48a), or -ik quantifiers (42a) and $-i k$ interrogatives (48b) are not topics, but they elicit agreement:
a. Mari csak a szintaxis dolgozat-ot ír-t-a meg. Mary only the syntax paper-ACC write-PST-3<3SG PRT 'Mary completed only the syntax paper.'
b. Melyik dolgozat-ot ír-t-a Mari? which paper-ACC write-PST-3<3SG Mary 'Which paper did Mary write?'

In the case of topical indefinites, we attest a vacillation between the definiteness condition and the topicality condition of object-verb agreement as late as the 18th century. Kelemen Mikes (1690-1761), for example, still uses the object agreement conjugation with an indefinite relative pronoun of object function (49a) - presumably because the antecedent of the pronoun renders it contextually given, i.e., topical. In Modern Hungarian, the non-agreeing verb form would be used (49b).

a. Boldog asszony az olyan, [aki-t gyermek-estől együtt vesz-ik meg] happy woman that one who-ACC child-SOCIAT together buy-3<3PL PRT 'That is a happy woman who is bought together with her child.'

(Middle Hungarian, Mikes 1794: 136)

b. Boldog asszony az olyan, [aki-t gyermek-estől együtt vesz-nek meg] (MH) happy woman that one who-ACC child-SOCIAT together buy-3PL PRT

The generalization of accusative marking to all objects (modulo relics of the Inverse Topicality Constraint) is related to the fact that the CP domain has become a pure A-bar domain not involved in case assignment. In Modern Hungarian, neither the subject, nor the object leave the vP unless they are moved into Spec,TopicP or Spec,FocusP, i.e., they obviously receive case in situ. This fact can be derived by assuming, following Richards (2011) and others, that T is the head of the lower phase of the Hungarian sentence. Under this assumption, case-assignment takes place in the domain of $\mathrm{T}$, with the filler of Spec, $\mathrm{vP}$ receiving unmarked case, and the filler of Spec, VP assuming dependent case. Since the CP is a pure A-bar domain, the noun phrases moved there inherit their cases from the lower links of their respective chains.

In sum: in Modern Hungarian, the correlation of nominative assignment and subject-verb agreement has lost its syntactic motivation, but it has largely survived in a morphologicized form. Accusative assignment, on the other hand, has been completely severed from object-verb agreement. Whereas object-verb agreement is restricted to definite objects, accusative case has been generalized to all objects. It has been argued that the split of agreement and case assignment is a consequence of the separation of the projections encoding discourse functions and the projections encoding the thematic hierarchy and grammatical functions. 


\section{SUMMARY, CONCLUSION}

The empirical facts of the various Ugric languages and dialects presented and discussed above can be summarized along four parameters: (i) whether the language displays topicality-induced subject-verb agreement; (ii) whether subject-verb agreement correlates with nominative assignment; (iii) whether the language displays topicality-induced object-verb agreement, and (iv) whether object-verb agreement correlates with accusative assignment. Our findings can be summarized as follows (Table 1):

Table 1. Correlation of topicality, agreement, and case assignment in the Ugric languages

\begin{tabular}{|l|c|c|c|}
\hline & Estern Mansi (Proto-Ugric) & EK, NK, NM & Hungarian \\
\hline Topical subject - verb agreement & + & + & - \\
\hline Agreeing subject is assigned nominative & + & + & $+?$ \\
\hline Topical object - verb agreement & + & + & - \\
\hline Agreeing object is assigned accusative & + & - & - \\
\hline
\end{tabular}

The comparison of the Ugric languages suggests that case assignment operates in tandem with agreement when discourse roles and grammatical functions are fused in sentence structure. The fusion of the primary topic and subject roles, and the secondary topic and object roles is still intact in the SOV clause structure of Eastern Mansi, the most conservative, by now extinct language of the Ugric family, and the correlation of subject-verb agreement with nominative assignment, and the correlation of object-verb agreement with accusative assignment is also complete in it. While SOV is the prevailing word order in the extant Ob-Ugric languages: Eastern Khanty, Northern Khanty, and Northern Mansi, as well, its rigidity is loosening, also allowing SVO, SVX orders. As a consequence, $\mathrm{Spec}, \mathrm{ObjP}$ is becoming a pure topic position; hence accusative assignment is severed from topic function and object-verb agreement; it is generalized to all objects. In Hungarian, which has developed a Topic Focus V XP* word order, the topic function is independent of grammatical roles. Accordingly, the correlation between subject-verb agreement and nominative assignment has weakened, and the correlation between object-verb agreement and accusative assignment has been completely lost.

The lost syntactic correlations, or fragments of them, have often been preserved in a fossilized form in morphology. In Hungarian, the primary topic - verb agreement of the SOV proto-language has changed into agreement with the most common exponent of the primary topic role, i.e., it survives as subject-verb agreement. Secondary topic - verb agreement has changed into agreement with the most typical exponent of the secondary topic role, i.e., it survives as definite object - verb agreement. The correspondence of subjects eliciting verbal agreement and exponents of nominative case survives as a strong tendency allowing for exceptions (nominative subjects in infinitival clauses). The correspondence of topical, agreeing objects and targets of accusative assignment has been less stable across the Ugric languages, and apparently, it has proved to be less prone to grammaticize. At the same time, the dialects which have morphological differential object marking (with an overt allomorph on pronouns, and a 
phonologically empty allomorph on lexical objects) have integrated into morphology the two most typical scenarios of the former, syntactically determined correlation: pronominal objects functioning as discourse-old, topical, hence case-marked elements, and lexical objects functioning as information foci, represented by caseless constituents. Indo-European languages with morphological differential object marking, assigning overt accusative case to object types high on the topicality scale: personal pronouns, [+human] NPs, or masculine and feminine NPs (often with animate referents) versus neutral ones, have also conserved former topic - accusative-marked object correlations.

The changing relation between case assignment and agreement attested in the different Ugric languages has shed new light on the nature of this connection. The fact that agreement and case assignment only correlate in a sentence structure where the primary topic role and the subject role have the same exponent suggests that the correlation is a consequence of discourse functions and grammatical functions being realized at the same structural level. In languages where discourse roles and grammatical functions are determined at different levels of clause structure, agreement is associated with the topic function, and cases encode the argument hierarchy in the vP. According to the evidence of the Ugric languages, the correlation of agreement and case is an epiphenomenon which arises in languages with fused discourse functions and grammatical roles, and is often preserved in morphology also after the fusion has ceased.

Classic case theory, with case assignment based on Agree, does not predict the varying relation of case and agreement attested in Ugric. The lack of accusative case on VP-internal objects in Eastern Mansi in apparent violation of the Case Filter also represents a problem for it. In the framework of Chomskyan case theory, VP-internal objects are usually analyzed as incorporated or pseudo-incorporated elements; however, Eastern Mansi caseless objects do not display the semantics of incorporated nominals; they can be referential and definite. The case theory that models the situation attested in Ugric most straightforwardly is the theory of dependent case, in which case encodes the hierarchy of arguments, and there is no inherent correlation between case and agreement. Dependent case theory can also handle the fact that VP-external objects bear accusative, VP-internal objects bear unmarked case in Eastern Mansi.

\section{ACKNOWLEDGEMENT}

This paper was written in the framework of grant 129921 of NKFIH, the National Research, Development and Innovation Office. I am grateful to my colleagues at the Research Institute for Linguistics, the audience of Cambridge Comparative Syntax 9, and the anonymous reviewers of the paper for their comments and useful advice.

\section{REFERENCES}

Abondolo, Daniel. 1998. Introduction. In Daniel Abondolo (ed.) The Uralic Languages. London: Routledge. $1-42$.

Asztalos, Erika, Katalin Gugán, and Nikolett Mus. 2017. Uráli VX szórend: nyenyec, hanti és udmurt mondatszerkezeti változatok [Uralic VX word order: Nenets, Khanty and Udmurt clause structure 
variants]. In Katalin É. Kiss, Attila Hegedűs, and Lilla Pintér (eds.) Nyelvelmélet és diakrónia 3. Budapest - Piliscsaba: PPKE BTK. 30-62.

Baker, Mark. 2008. The syntax of agreement and concord. Cambridge: Cambridge University Press.

Baker, Mark. 2012. On the relationship of object agreement and accusative case: Evidence from Amharic. Linguistic Inquiry 43. 255-274.

Baker, Mark. 2014. On dependent ergative case (in Shipibo) and its derivation by phase. Linguistic Inquiry 45. 341-379.

Baker, Mark. 2015. Case. Cambridge: Cambridge University Press.

Baker, Mark and Nadezhda Vinokurova. 2010. Two modalities of case assignment in Sakha. Natural Language and Linguistic Theory 28. 593-642.

Bárány, András. 2015. Inverse agreement and Hungarian verb paradigms. In Katalin É. Kiss, Balázs Surányi and Éva Dékány (eds.) Approaches to Hungarian 14. Amsterdam: John Benjamins. 37-64.

Bárány, András. 2018a. DOM and dative case. Glossa: A Journal of General Linguistics 3(1). 97. http://doi. org/10.5334/gjgl.639.

Bárány, András. 2018b. Person, case, and agreement. Oxford: Oxford University Press.

Bartos, Huba. 2000. Az inflexiós jelenségek szintaktikai háttere [The syntactic background of Hungarian inflection phenomena]. In Ferenc Kiefer (ed.) Strukturális magyar nyelvtan 3. Morfológia. Budapest: Akadémiai Kiadó. 653-760.

Bartos, Huba. 2001. Object agreement in Hungarian: A case for Minimalism. In Galina M. Alexandrova and Olga Arnaudova (eds.) The minimalist parameter. Amsterdam: John Benjamins. 311-324.

Bartos, Huba. 2006. “És mégis mozog” [“Eppur si muove”]. In László Kálmán (ed.) KB 120: A titkos kötet. Budapest: Tinta Kiadó. 29-67.

Beck, Sigrid and Kyle Johnson. 2004. Double objects again. Linguistic Inquiry 35(1). 97-123.

Béjar, Susana and Milan Rezac. 2009. Cyclic agree. Linguistic Inquiry 40(1). 35-73.

Bíró, Bernadett. 2015. Az északi és déli manysi ditranzitív szerkezetek szórendje [The word order of Northern and Southern Khanty ditransitive structures]. In Katalin É. Kiss, Attila Hegedüs, and Lilla Pintér (eds.) Nyelvelmélet és dialektológia 3. Budapest - Piliscsaba: PPKE BTK. 43-58.

Bíró, Bernadett and Katalin Sipöcz 2017. The Mansi ditransitive constructions. Finno-Ugric Languages and Linguistics 6(1). 41-55.

Bobaljik, Jonathan D. 2008. Where is phi? Agreement as a post-syntactic operation. In Daniel Harbour, David Adger, and Susana Béjar (eds.) Phi-theory: Phi features across interfaces and modules. Oxford: Oxford University Press. 295-328.

Bobaljik, Jonathan and Philip Branigan. 2006. Eccentric agreement and multiple Case-checking. In Alana Johns, Diane Massam, and Juvenal Ndayiragije (eds.) Ergativity: Emerging issues. Dordrecht: Kluwer. 44-77.

Bruening, Benjamin. 2013. By-phrases in passives and nominals. Syntax 16. 1-41. https://doi.org/10.1111/j. 1467-9612.2012.00171.x.

Chen, Tingchun. 2018. Multiple case assignment: An Amis case study. PhD dissertation. Cambridge, MA: MIT.

Chomsky, Noam. 2000. Minimalist inquiries: The framework. In Roger Martin, David Michaels, and Juan Uriagereka (eds.) Step by step. Cambridge, MA: MIT Press. 89-155.

Chomsky, Noam. 2001. Derivation by phase. In Michael Kenstowicz (ed.) Ken Hale: A life in language. Cambridge, MA: MIT Press. 1-52.

Comrie, Bernard. 1980. Inverse verb forms in Siberia: Evidence from Chukchee, Koryak and Kamchadal. Folia Linguistica 1. 61-74. 
Coppock, Elisabeth. 2013. A semantic solution to the problem of Hungarian object agreement. Natural Language Semantics 21(4). 345-371.

Coppock, Elisabeth and Stephen Wechsler. 2012. The objective conjugation in Hungarian: Agreement without phi-features. Natural Language and Linguistic Theory 30(3). 699-740.

Csepregi, Márta 1997. Russische Einflüsse in der Südostjakischen Syntax. In Sirkka-Liisa Hahmo, Tette Hofstra, László Honti, Paul van Linde, and Os Nikkila (eds.) Finnisch-ugrische Sprachen in Kontakt. Maastricht: Shaker Publishing. 71-77.

Csepregi, Márta. 1998. Szurguti osztják chrestomathia. Szeged: JATE.

Csepregi, Márta 2019. Kontaktusjelenségek az északnyugat-szibériai nyelvi areában [Contact phenomena in the linguistic area of North-Western Siberia]. In Katalin É. Kiss, Attila Hegedüs, and Lilla Pintér (eds.) Nyelvelmélet és kontaktológia 4. Budapest - Piliscsaba: PPKE BTK. 77-102.

Dalrymple, Mary and Irina Nikolaeva. 2011. Objects and information structure. Cambridge: Cambridge University Press.

Décsy, Gyula. 1990. The Uralic protolanguage: A comprehensive reconstruction. Bloomington: Indiana University.

Dékány, Éva, Katalin Gugán, and Orsolya Tánczos 2020. Contact-induced change in Surgut Khanty relative clauses. Folia Linguistica 54(1). 1-44.

Den Dikken, Marcel. 2006. Where Hungarians agree (to disagree): The fine structure of 'phi' and 'art.' Ms., CUNY Graduate Center.

Dixon, Robert M. W. 1994. Ergativity. Cambridge: Cambridge University Press.

É. Kiss, Katalin. 2013. The inverse agreement constraint in Uralic languages. Finno-Ugric Languages and Linguistics 2(1). 2-21.

É. Kiss, Katalin. (ed.). 2014. The evolution of functional left peripheries in Hungarian syntax. Oxford: Oxford University Press.

É. Kiss, Katalin. 2017. The person-case constraint and the inverse agreement constraint are manifestations of the same inverse topicality constraint. The Linguistic Review 34(2). 365-395.

É. Kiss, Katalin. 2020a. Syntactic reconstruction based on linguistic fossils: Object-marking in Uralic. In Jóhannes Gísli Jónsson and Thórhallur Eythórsson (eds.) Syntactic Features and the Limits of Syntactic Change. Oxford: Oxford University Press.

É. Kiss, Katalin. 2020b. Accusative or possessive? The suffix of pronominal objects in Ob-Ugric. FinnoUgric Languages and Linguistics 9(1-2). 1-12.

É. Kiss, Katalin and Orsolya Tánczos. 2018. From possessor agreement to object marking: the functional evolution of the Udmurt -jez suffix. Language 94. 733-757.

Filchenko, Andrey. 2007. A Grammar of Eastern Khanty. PhD dissertation. Houston: Rice University.

Givón, Talmy. 1975. Topic, pronoun, and grammatical agreement. In Charles Li, and Sandra Thompson (eds.) Subject and topic. New York: Academic Press. 149-188.

Gulya, János. 1970. Aktiv, ergative and passive im Vach-Ostjakischen. In Wolfgang Schlachter (ed.) Symposion über Syntax der uralischen Sprachen. Göttingen: Vandenhoeck \& Ruprecht.

Harley, Heidi. 2003. Possession and the double object construction. Linguistic Variation Yearbook 2. 3170.

Honti, László. 1982. Das Passiv in den obugrischen Sprachen. Acta Linguistica Academiae Scientiarum Hungaricae 32. 39-51.

Kálmán, Béla. 1976a. Chrestomathia Vogulica. Budapest: Tankönyvkiadó.

Kálmán, Béla. 1976b. Wogulische Texte mit einem Glossar. Budapest: Akadémiai Kiadó.

Kiparsky, Paul. 2001. Structural case in Finnish. Lingua 111. 315-376. 
Kiparsky, Paul. 2013. Towards a null theory of the passive. Lingua 125. 7-33.

Kulonen, Ulla-Maija. 1989. The Passive in Ob-Ugrian. MSFOu 203. Helsinki: Finno-Ugrian Society.

Kulonen, Ulla-Maija. 2007. Itämansin kielioppi ja tekstejä. Helsinki: Suomalais-ugrilainen Seura.

Larson, Richard K. 1988. On the double object construction. Linguistic Inquiry 19. 335-391.

Lavothe, Ödön. 1958. A manysi intranzitív igék passzívumáról [On the passive voice of Mansi intransitive verbs]. Nyelvtudományi Közlemények 60. 93-100.

Legate, Julie. 2008. Morphological and abstract case. Linguistic Inquiry 39. 55-102.

Levin, Beth. 2008. Dative verbs: A crosslinguistic perspective. Lingvisticæ Investigationes 31. 285-312.

Marantz, Alec. 1991. Case and licensing. Paper presented at The 8th Eastern States Conference on Linguistics. University of Maryland.

Marcantonio, Angela. 1985. On the definite vs. indefinite conjugation in Hungarian: A typological and diachronic analysis. Acta Linguistica Academiae Scientiarum Hungaricae 35(3-4). 267-298.

Mikes, Kelemen. 1794. István Kultsár (ed.), Törökországi levelek. Szombathely: Siess Antal.

Moravcsik, Edith. 1974. Object-verb agreement. Working Papers in Language Universals 15. 25-140. Stanford: Stanford University.

München Codex 1416/1466. In Antal Nyíri (ed.) A Müncheni Kódex 1466-ból. Kritikai szövegkiadás a latin megfelelővel együtt, 1971. Budapest: Akadémiai Kiadó.

Nikolaeva, Irina. 1999. Ostyak. München: Lincom Europa.

Nikolaeva, Irina. 2001. Secondary topic as a relation in information structure. Linguistics 39(1). 1-49.

Nikolaeva, Irina. 2003. Possessive affixes in the pragmatic structuring of the utterance: Evidence from Uralic. In Pirkko Suihkonen and Bernard Comrie (eds.) International symposium on deictic systems and quantification in languages spoken in Europe and North and Central Asia. Collection of Papers. Izhevsk - Leipzig: Udmurt State University and Max Planck Institute for Evolutionary Anthropology. $130-145$.

OUDB EM: Obi-Ugric Database Eastern Mansi Corpus http://www.babel.gwi.uni-muenchen.de/index.php? abfrage=EM_corpus\&subnavi $=$ corpus_pub.

Rappaport Hovav, Malka and Beth Levin. 2008. The English dative alternation: The case for verb sensitivity. Journal of Linguistics 44. 129-167.

Richards, Marc D. 2011. Deriving the Edge: What's in a Phase? Syntax 14(1). 74-95.

Richards, Norvin. 2017. Multiple case assignment and the English pseudo-passive. In Nicholas LaCara, Keir Moulton, and Anne-Michelle Tessier (eds.) A Schrift to Fest Kyle Johnson. Linguistics Open Access Publications. 313-319.

Riese, Timothy. 2001. Vogul. Languages of the World/Materials 158. München: Lincom Europa.

Rizzi, Luigi. 2006. On the form of chains: Criterial positions and ECP effects. In Lisa Cheng and Norbert Corver (eds.) On Wh movement: Moving on. Cambridge, MA: MIT Press. 97-134.

Rizzi, Luigi, and Ur Shlonsky. 2007. Strategies of subject extraction. In Uli Sauerland and Hans-Martin Gärtner (eds.) Interfaces + Recursion = Language? Berlin: Mouton de Gruyter. 117-160.

Rocquet, Amélie. 2013. Splitting objects: A nanosyntactic account of direct object marking. PhD dissertation, Ghent University.

Silverstein, Michael. 1976. Hierarchy of features and ergativity. In Robert M. W. Dixon (ed.) Grammatical categories in Australian languages. Atlantic Highlands, NJ: Humanities Press. 112-171.

Sipőcz, Katalin. 2015. Tárgyjelölés a manysi ditranzitív szerkezetekben [Object marking in Mansi ditransitive constructions]. In Katalin É. Kiss, Attila Hegedűs, and Lilla Pintér (eds.) Nyelvelmélet és dialektológia 3. Budapest - Piliscsaba: PPKE BTK. 234-246. 
Sipőcz, Katalin. 2016. A manysi ditranzitív igék szintaxisa szemantikai megközelítésből [The syntax of Mansi ditransitive verbs from a semantic aspect]. Jelentés és Nyelvhasználat 3. 49-61.

Skribnik, Elena. 2001. Pragmatic structuring in Northern Mansi. In Tönu Seidenthal (ed.) Congressus

Nonus Internationalis Fenno-ugristarum. Pars IV. Dissertationes sectionum: Linguistica III. Tartu: Tartu University. 222-239.

Smith, Peter W. To appear. Object agreement and grammatical functions: A re-evaluation. In Peter W. Smith, Katharina Hartmann, and Johannes Mursell (eds.) Agree to agree: Agreement in the minimalist programme. Berlin: Language Science Press.

Sosa, Sachiko. 2017. Functions of morphosyntactic alternations, and information flow in Surgut Khanty discourse. PhD dissertation. University of Helsinki.

Szabolcsi, Anna. 2005. Overt infinitival subjects (if that's what they are...). In Hans Broekhuis, Norbert Corver, Riny Huijbregts, Ursula Kleinhenz, and Jan Koster (eds.) Organizing Grammar. Festschrift for Henk van Riemsdijk. Berlin: De Gruyter. 618-625.

Szabolcsi, Anna. 2007. Overt nominative subjects in infinitival complements in Hungarian. In Marcel den Dikken and Robert M. Vago (eds.) Approaches to Hungarian 11. Amsterdam: John Benjamins. 251276.

Typological database of the Ugric languages. http://hu.utdb.nullpoint.info.

Virtanen, Susanna. 2014. Pragmatic object marking in Eastern Mansi. Linguistics 52(2). 391-413.

Virtanen, Susanna. 2015. Transitivity in Eastern Mansi. An information structural approach. PhD dissertation. University of Helsinki.

Open Access. This is an open-access article distributed under the terms of the Creative Commons Attribution 4.0 International License (https://creativecommons.org/licenses/by/4.0/), which permits unrestricted use, distribution, and reproduction in any medium, provided the original author and source are credited, a link to the CC License is provided, and changes - if any - are indicated. (SID_1) 